\title{
Marjin Pemasaran Ternak Kerbau di Pasar Hewan Bolu Kabupaten Toraja Utara
}

\author{
(Margin of Buffalo Marketing at the Bolu Animal Market, North Toraja District)
}

\author{
Isbandi, Soeharsono, Rusdiana S \\ Balai Penelitian Ternak, PO Box 221, Ciawi, Bogor 16002 \\ idnabsi@yahoo.co.id
}

\begin{abstract}
Research to determine the buffaloes marketing margin have been conducted in Bolu animals Market Tallunglipu Matallo villages, sub districts Tallunglipu, North Toraja district, in February 2017. Data collection was obtained from the method of field surveys and direct interviews. Respondents consisted of 25 merchants buffaloes, which were divided into large-scale trader as many as 12 people, eight small scale traders and five middle cattle traders. Data collected were the number of buffaloes in the animal market, the initial price and the selling price. Secondary data and primary data obtained from various research field and from the local Animal Husbandry Department. The data were analyzed descriptively and quantitatively. The results showed that, not all the buffaloes are brought to market to be sold on the market, therefore middle cattle traders appears, which has the task of maintaining and serve as middlemen, and get a share of $2.5 \%$ of the price selling. Marketing margin on the condition of the cattle brought to be sold on the market in the same day is $8-10 \%$ of the initial purchase price.
\end{abstract}

Key Words: Animal Market, Buffalo, Animal Trader, Market Margin

\begin{abstract}
ABSTRAK
Penelitian untuk mengetahui besarnya marjin pemasaran ternak kerbau telah dilakukan di Pasar Hewan Bolu, Kelurahan Tallunglipu Matallo, Kecamatan Tallunglipu, Kabupaten Toraja Utara, pada bulan Februari tahun 2017. Data dikumpulkan melalui metode survei lapang dan wawancara langsung. Responden terdiri dari 25 orang pedagang kerbau, terdiri dari 12 orang pedagang skala besar, delapan orang pedagang skala kecil dan lima pedagang ternak titipan. Informasi dan data yang dikumpulkan meliputi jumlah ternak kerbau di pasar hewan, harga beli dan harga jual. Data sekunder dan primer diperoleh dari berbagai hasil penelitian lapang dan dari dinas peternakan setempat. Data yang terkumpul dianalisis secara deskriptif dan kuantitatif. Hasil penelitian menunjukkan bahwa tidak semua ternak kerbau yang dibawa ke pasar akan laku pada hari pasar tersebut. Oleh karena itu, muncul pelaku pasar yakni pedagang titipan, yang mempunyai tugas memelihara dan berfungsi sebagai pedagang perantara dan mendapatkan bagian sebesar 2,5\% dari harga jual. Marjin pemasaran pedagang pengumpul pada kondisi ternak yang dibawa dapat terjual pada hari pasar itu juga sebesar 8-10\% dari harga awal pembelian.
\end{abstract}

Kata Kunci: Pasar Hewan, Kerbau, Pedagang Ternak, Margin Pemasaran

\section{PENDAHULUAN}

Ternak kerbau memegang peranan yang sangat penting bagi status sosial dan budaya masyarakat di wilayah Tana Toraja, Sulawesi Selatan. Sejak dahulu, masyarakat berpendapat bahwa apabila seseorang memiliki ternak kerbau, khususnya jenis kerbau belang maka dianggap sebagai orang yang memiliki harta banyak dan berderajat tinggi. Keberadaan ternak kerbau dimanfaatkan pada acara-acara tertentu sebagai simbol kebesaran seperti pada acara kematian bagi anggota keluarga yang meninggal dunia, yang disebut Rambu Solo. 
Sariubang et al. (2010) menyatakan bahwa upacara kematian yang dilakukan tidak sedikitpun melambangkan upacara kematian tetapi lebih berupa pesta perayaan. Karena itu upacara kematian ini sering disebut pesta adat. Mereka meyakini bahwa dengan mengadakan upacara adat ini roh si mati dapat diiring sampai mencapai nirwana keabadian. Pada upacara kematian ini penggunaan simbol-simbol sangat berperan penting, salah satunya adalah penggunaan simbol kerbau sebagai syarat utama dalam upacara kematian Rambu Solo (pemakaman).

Yulius (2012) melaporkan walaupun secara umum kerbau mempunyai nilai sosial tinggi, namun orang Toraja mempunyai cara menilai kerbau mereka. Tinggi rendahnya nilai kerbau tergantung pada mutu kerbau menurut penilaian yang berlaku umum, dan nampaknya sudah dipakai turun temurun sejak jaman nenek moyang. Penilaian ini juga berlaku bagi para pedagang kerbau saat ini dalam menentukan harga. Mutu kerbau dapat dilihat dalam cara orang Toraja sendiri menilai khususnya untuk kerbau belang berdasarkan karakteristik yang dimilikinya. Secara umum, orang Toraja menilai kerbau dari tanduk, warna kulit dan bulu, dan postur, serta tanda-tanda di badan. Salah satu bukti demikian pentingnya kerbau dalam kebudayaan orang Toraja adalah dengan adanya sejumlah kategori dari berbagai macam jenis kerbau. Dalam upacara adat Toraja seperti Rambu Solo, kerbau memegang peranan sebagai piranti utama. Kerbau digunakan sebagai alat pertukaran sosial dalam upacara tersebut. Jumlah kerbau yang dikorbankan menjadi salah satu tolok ukur kekayaan atau kesuksesan anggota keluarga yang sedang menggelar acara. Kebanggaan akan hal tersebut terlihat dari jumlah tanduk kerbau yang dipasang pada bagian depan Tongkonan (rumah tradisional Toraja) keluarga penyelenggara upacara Rambu Solo. Jumlah kerbau yang dipersembahkan bisa mencapai ratusan ekor dan menghabiskan dana hingga miliaran rupiah. Keadaan tersebut menyebabkan harga seekor kerbau belang jantan yang akan digunakan sebagai persembahan mencapai ratusan juta rupiah, bergantung pada pola atau tipe belangnya, ukuran/bobot badan serta tipe tanduknya.

Pemasaran ternak kerbau dapat dikatakan sebagai ciri pasar pada suatu produk hasil peternakan yang bersifat monopsonistis, dimana biasanya peternak hanya sebagai price taker bukan price maker baik didalam memasok input maupun dalam menyalurkan output (produksinya). Menurut Elizabeth \& Rusdiana (2011) dengan adanya lembaga pemasaran, diharapkan dapat membantu cara pemindahan suatu produk yang dihasilkan oleh produsen untuk dipasarkan, sehingga produk diharapkan dapat diketahui dan bemanfaat untuk kebutuhan konsumen. Pemasaran merupakan muara akhir dari suatu aktivitas pedagang dan pembeli dengan cara memasarkan hasil produksinya untuk kebutuhan konsumen dilokasi yang telah disediakan. Kotler dan Amstrong (1995) menyatakan bahwa teori dalam menentukan harga jual suatu produk berdasarkan pada biaya yang dikeluarkan, ketersediaan pasokan/suplai persedian, kemampuan pesaing dan harga pesaing. Akan tetapi para pelaku di Pasar Hewan Bolu Kabupaten Toraja tidak menggunakan teori tersebut dalam menentukan harga jual.

Pasar Hewan Bolu, Kecamatan Tallunglipu, Kabupaten Toraja Utara merupakan salah satu pasar yang memiliki ciri khas tersendiri di Kabupaten Toraja Utara. Pasar Hewan Bolu juga dikenal sebagai Pasar Hewan Rantepao. Aktivitas pemasaran ternak kerbau berlangsung setiap enam hari dalam seminggu. Adapun ternak yang di pasarkan terdiri dari ternak kerbau lokal, ternak kerbau yang berasal daerah lain, dan ternak babi. Saat ini keberadaan pasar hewan bukan hanya sebagai salah satu sumber pandapatan asli daerah yang bersumber dari pemungutan retribusi pasar, akan tetapi juga sebagai objek wisata bagi wisatawan baik domestik maupun mancanegara. Hal ini dikarenakan adanya keunikan-keunikan yang terjadi dalam pemasaran ternak atau hewan yang sangat berbeda dengan pemasaran ternak atau hewan di daerah-daerah atau wilayah lain. 
Seperti di tempat lainnya, harga ternak kerbau berfluktuasi. Fluktuasi harga sangat dipengaruhi oleh ketersediaan dan permintaan konsumen. Apabila terjadi keseimbangan antara penawaran dan permintaan, maka akan terjadi kecenderungan transaksi jual beli dengan harga yang berlaku.

Pemasaran dapat dikatakan efisien, apabila mampu menjual hasil produksi kepada konsumen dengan biaya semurah-murahnya dan mampu mengadakan pembagian keuntungan yang adil dari keseluruhan harga yang dibayar konsumen kepada semua pihak yang ikut serta dalam kegiatan produksi dan tataniaga. Sedangkan menurut Emhar et al. (2014) margin pemasaran merupakan bagian dari semua biaya yang dibayarkan dan pendapatan yang diterima oleh setiap mata rantai pemasaran, yang terlibat dalam proses rantai pasok. Rantai pemasaran yang panjang tidak efisien karena konsumen akan terbebani dengan biaya pemasaran yang berat untuk membayar biaya yang sangat tinggi. Hampir semua pedagang di Pasar Hewan Bolu Kabupaten Toraja Utara tidak merasa terbebani dengan biaya distribusi, karena harga ternak kerbau sesuai dengan nilai dan kepuasan konsumen. Abubakar (2002) menyatakan bahwa, margin pemasaran dapat didefinisikan sebagai perbedaan antara harga yang dibayarkan oleh konsumen dan harga yang diterima oleh produsen.

Berdasarkan permasalahan tersebut di atas, maka tujuan penelitian ini adalah untuk mengetahui rantai tata niaga, dan besarnya margin pemasaran yang diterima oleh masingmasing pelaku pemasaran ternak kerbau di Pasar Hewan Bolu, Rantepao, Toraja Utara.

\section{MATERI DAN METODE}

Penelitian dilakukan di Pasar Hewan Bolu, Kelurahan Tallunglipu Matallo, Kecamatan Tallunglipu, Kabupaten Toraja Utara, Provinsi Sulawesi Selatan pada bulan Februari tahun 2017 dengan menggunakan metoda survei. Data diperoleh dengan cara wawancara langsung dengan pedagang kerbau sebanyak 25 orang, terdiri dari 12 pedagang besar, delapan pedagang kecil dan lima orang pedagang titipan secara sampling aksidental (pengambilan sampel responden yang kebetulan ditemui) karena memiliki jumlah populasi yang banyak.

Data primer diambil saat wawancara, meliputi jumlah ternak kerbau di Pasar Hewan Bolu, jumlah kerbau yang terjual, harga jual kerbau di tingkat pasar hewan dan marjin pemasaran di masing-masing pedagang. Sedangkan data sekunder diperoleh dari berbagai hasil penelitian lapang dan Dinas Peternakan Kabupaten Toraja Utara. Data yang terkumpul dianalisis secara diskriptif dan kuantitatif berdasarkan hari pasar I, dan hari pasar II apabila ternak tidak terjual pada hari pasar I. Untuk menentukan harga jual, pada kasus ternak tidak terjual pada hari pasar pertama dengan rumus: harga pokok + marjin penjualan + biaya pemeliharaan + biaya risiko $10 \%$ dari harga pokok pembelian .

\section{HASIL DAN PEMBAHASAN}

\section{Keadaan umum wilayah penelitian}

Kabupaten Toraja Utara, yang beribukota di Rantepao. merupakan salah satu Kabupaten di Provinsi Sulawesi Selatan. Kabupaten ini dibentuk berdasarkan UndangUndang Nomor 28 Tahun 2008 yang merupakan pemekaran dari Kabupaten Tana Toraja, terletak di sebelah utara Kabupaten Tana Toraja dengan posisi antara $2^{\circ} 35^{\prime \prime}$ LS-3 ${ }^{\circ} 15^{\prime}$ ' LS dan $119^{\circ}-120^{\prime}$ ' Bujur Timur dengan luas wilayah $1.151,47 \mathrm{~km}^{2}$ terdiri dari hutan lindung 47.900 ha, hutan rakyat 5.260 ha, 12.790,93 ha, dan kebun 14,620 ha. Permukiman 9.865 ha dan berada pada ketinggian 704-1.646 m dpl. Secara administratif, wilayah Kabupaten 
Toraja Utara berbatasan dengan Kabupaten Sulawesi Barat dan Kabupaten Luwu, sebelah Selatan dengan Kabupaten Tana Toraja, sebelah barat dengan Kabupaten Sulawesi Barat, dan di sebelah timur berbatasan dengan Kabupaten Luwu Timur (Distannak Kabupaten Toraja Utara 2016).

Lahan pekarangan selain digunakan sebagai tempat pemukiman penduduk, juga dimanfaatkan untuk budidaya tanaman dan peternakan khususnya usaha ternak kerbau. Wilayah Kabupaten Toraja Utara adalah salah satu dari tujuh kabupaten di Sulawesi Selatan yang mempunyai potensi besar di bidang peternakan khususnya ternak kerbau. Data yang diperoleh dari dinas pertanian setempat menunjukkan bahwa populasi ternak kerbau pada tahun 2015 sebesar 76.761 ekor. Jumlah tersebut mengalami penurunan apabila dibandingkan dengan tahun-tahun sebelumnya. Penurunan populasi terjadi akibat dari tingginya tingkat pemotongan kerbau tanpa dibarengi dengan kelahiran, karena bagi masyarakat Toraja komoditas kerbau mempunyai peran yang sangat penting dalam kaitannya dengan ritual upacara pemakaman yang ditandai dengan pemotongan kerbau berbagai tipe (Belang, Pudu, Todi, Sambao, Balian) mulai 1-2 ekor sampai 10 ekor bahkan lebih dari 100 ekor setiap kegiatan upacara adat kedukaan, selain untuk konsumsi. Oleh karena itu, pemotongan kerbau di Kabupaten Tana Toraja mencapai angka \pm 8.500 ekor setiap tahun (Disnak Kabupaten Toraja Utara 2012). Penurunan populasi terjadi mulai tahun 2000 karena kelahiran belum dapat mengimbangi permintaan pasar yang cenderung meningkat. Oleh karena itu, kondisi saat ini sekitar 70\% dari kebutuhan, mulai dipasok dari luar kabupaten seperti: Takalar, Jeneponto, Bantaeng, Wajo, Palopo, Bone dan bahkan dari luar provinsi seperti NTT, NTB, Kalimantan, Ambon, Sulawesi Tengah dan Sulawesi Tenggara. Untuk mendapatkan ternak kerbau dalam waktu yang singkat dengan jumlah yang banyak serta umur tertentu tidaklah mudah, masalah yang dihadapi peternak tidak mempunyai akses langsung ke konsumen dan kendala jarak lokasi pembeli dan penjual yang relatif jauh (Saleh et al. 2012).

Meningkatnya populasi ternak kerbau yang seimbang dengan kebutuhan dapat memberikan dampak positif, apalagi bila dikaitkan dengan keberadaan ternak kerbau sebagai kelengkapan dari upacara adat. Posisi ternak kerbau di Kabupaten Toraja Utara merupakan salah satu komoditas yang sangat penting karena dalam upacara kematian Rambu Solo dilaksanakan berdasarkan status sosial yang meninggal yaitu pesta besar hanya dapat dilaksanakan kalangan atas saja dan pesta yang paling tinggi disebut Rapasan Sapu Randanan dimana pestanya berlangsung minimal sampai satu minggu dan menghabiskan ratusan ekor kerbau dan ribuan ekor ternak babi (Sariubang 2010). Oleh karena pentingnya posisi ternak kerbau tersebut, memberikan peluang yang cukup besar bagi pedagang kerbau, baik dari luar daerah maupun dari wilayah Tana Toraja.

\section{Jenis, ciri, harga ternak kerbau di Pasar Hewan Bolu}

Salah satu ternak besar yang bernilai ekonomis yaitu kerbau (Bubalus bubalis). Kerbau adalah binatang yang cukup banyak diperjualbelikan di sekitar wilayah Tana Toraja dan bisa ditemukan jenis kerbau yang sangat unik dan hanya terdapat di Toraja yaitu kerbau belang. Orang Toraja menyebutnya Tedong Bonga. Sedangkan kualitas kerbau dapat dilihat dari cara masyarakat Tana Toraja yang mengelompokkan kerbau berdasarkan jenis yang mereka kenal. Salah satu bukti demikian pentingnya kerbau dalam kebudayaan orang Toraja adalah dengan adanya sejumlah kategori dari berbagai macam jenis kerbau yang umumnya dilihat dari ukuran tubuh, bentuk, tanduk, serta perpaduan warna kulitnya antara warna dasar putih serta belang hitam, dengan tanduk berwarna kuning gading dan bola mata berwarna putih seperti kaca. Bentuk tanduk kerbau menentukan nilainya, namun peran tanduk bagi kerbau jantan lebih penting dibandingkan 
pada kerbau betina. Biasanya ukuran dan bentuk tanduk kerbau betina tidak terlalu diperhitungkan. Tanduk kerbau jantan biasanya dijadikan sebagai alat dekoratif yang bermakna dalam masyarakat. Di rumah-rumah Tongkonan, tanduk kerbau disusun di depan rumah sebagai simbol status seseorang. Ada beberapa jenis kerbau yang diurutkan berdasarkan kualitasnya yakni Tedong Saleko yang dianggap paling baik oleh masyarakat, diikuti oleh Tedong Bonga dan Lotong Boko. Sedangkan perbedaan yang paling mendasar terletak pada warna dasar dari kulit kerbau, yakni berwarna dasar hitam dengan belang putih.

Karakteristik kerbau di Pasar Hewan Bolu cukup bervariasi, baik dari warna kulit dan jenis serta ciri lainnya. Apabila dibedakan berdasarkan jenis kelaminnya, maka kerbau jantan dewasa merupakan jenis kelamin yang paling dominan dan diperkirakan mencapai $65 \%$ dari jumlah populasi di pasar, diikuti oleh jantan dan betina muda (20\%) serta jenis kerbau betina yang sudah tidak produktif $(15 \%)$. Keberadaan kerbau jantan, selain untuk dipotong juga digunakan sebagai pejantan. Sedangkan jantan dan betina muda dibeli untuk dipelihara sebagai ternak bakalan dan calon bibit. Sedikitnya 500 ekor kerbau dipasarkan setiap hari pasar dengan melibatkan beberapa pelaku pasar yakni peternak (produsen), pedagang perantara dan konsumen (pembeli). Hasil wawancara menunjukkan bahwa peranan pedagang perantara cukup dominan, karena hampir semua transaksi jual beli yang dilakukan di Pasar Hewan Bolu selalu melibatkan pedagang perantara. Keberadaan pedagang perantara sudah menyatu menjadi satu sistem pemasaran dan sudah terjadi secara turun temurun. Sedangkan tingkat harga ternak yang dipasarkan juga sangat bervariasi, tergantung kepada kualitas kerbau dan tujuan pembeliannya, yakni untuk konsumsi atau untuk kepentingan ritual, khususnya untuk dijadikan simbol dalam upacara adat (Distannak Kabupaten Toraja Utara 2016).

\section{Deskripsi pedagang dan alur pasar ternak kerbau}

Berbagai pelaku ekonomi khususnya bidang pemasaran memanfaatkan peluang untuk memperoleh keuntungan dengan memanfaatkan sumber daya yang ada, berlaku pada berbagai tingkatan pedagang mulai dari pedagang besar, pedagang kecil, pedagang perantara dan pedagang titipan. Beberapa langkah strategi yang ditempuh dalam pengembangan usaha untuk mendapatkan keuntungan pada perdagangan kerbau adalah dengan cara perbaikan pemeliharaan. Dengan cara ini peternak memanfaatkan peluang tersebut. Usaha ini harus memperhatikan penyediaan pakan yang berkualitas dengan jumlah yang cukup dalam rangka meningkatkan produksi dan nilai tambah setiap unit ternak. (Disnak Provinsi Sulawesi Selatan 2013).

Hasil wawancara dengan petugas dinas peternakan setempat dapat digambarkan bahwa ragam pedagang terdiri dari: pedagang pengumpul yaitu pedagang yang rajin berkunjung dari satu tempat ke tempat lain untuk membeli kerbau. Pedagang pengumpul inilah yang merupakan pemegang jalur pertama, karena langsung berhadapan dengan peternak/pedagang. Keberadaan pedagang pengumpul menyebabkan peternak tidak selalu memasarkan kerbau langsung ke konsumen akhir. Menurut Panggau (2014) peternak sebagai produsen berada di awal jalur pemasaran, sedangkan pedagang pengumpul berada di jalur pertama. Pedagang pengumpul sebagai rantai pertama yang langsung berhadapan dengan peternak dan harga yang ditawarkannya ini disebut harga peternakan (farm gate price) yang tentu lebih rendah dari harga eceran di tingkat konsumen akhir. Namun dalam prakteknya pedagang pengumpul bersedia juga membeli kerbau dari peternak/pedagang lainnya karena ternak tidak laku terjual pada hari pasar, namun dengan harga yang lebih rendah, karena harus mempertimbangkan faktor risiko yang dihadapi, seperti harus 
mengeluarkan biaya pemeliharaan dan menanggung risiko lain seperti ternak sakit, pembelian obat, vitamin dan bahkan risiko apabila terjadi kematian ternak.

Hubungan antara pedagang pengumpul, pedagang kecil dan pedagang titipan ternak kerbau, dijembatani oleh pedagang perantara. Sistem pemasaran ternak kerbau yang demikian sudah berjalan cukup lama, meskipun secara formal tidak ada peraturan yang mengikat, namun sudah menjadi tradisi turun temurun. Pedagang perantara bertugas menghubungkan calon pembeli (konsumen) dan produsen. Namun demikian, dalam transaksi jual beli, mekanisme tawar menawar harga sampai dengan terjadinya kesepakatan harga berada di pihak pedagang perantara, dengan tetap berpedoman pada harga yang diminta oleh pemilik ternak. Dalam kegiatan transaksi jual beli, pedagang perantara akan mendapatkan bagian sebesar 2-2,5\% dari nilai jual ternak.

Berdasarkan survei yang dilakukan di lapangan menunjukkan bahwa pedagang kerbau di Pasar Hewan Bolu mengharapkan ternak yang mereka jual laku dan habis terjual akan tetapi kenyataan di lapangan ternak kerbau sering tidak habis terjual pada hari pasar berjalan dan akan dijual pada hari pasar berikutnya. Untuk menunggu pasar berikutnya pelaku pemasaran memanfaatkan kandang yang tersedia di pasar hewan, yang tentunya dikenakan biaya sewa di samping biaya-biaya lainnya (pakan, vitamin, obat-obatan, tenaga kerja dan lain-lain). Kondisi seperti ini menimbulkan ragam penjual lain yang disebut dengan pedagang titipan. Pedagang kerbau titipan mempunyai peran seperti pedagang lainnya, perbedaannya terletak pada kepemilikan tempat dan peranannya dalam menjalankan kegiatannya. Tugas tambahan yang akan dikerjakan oleh pedagang titipan adalah memelihara ternak titipan sepanjang ternak tersebut belum terjual. Oleh karena itu, sisa ternak yang tidak terjual akan dititipkan kepada pedagang titipan, dengan mandat untuk bisa menjualnya dengan kesepakatan harga yang sudah ditentukan. Biasanya pedagang titipan akan menjual ternak titipan dengan harga yang lebih dari kesepakatan dengan pemilik, sebagai keuntungannya.

Perhitungan dari harga yang dibayar oleh konsumen dapat digambarkan sebagai presentase dari harga dari setiap marjin pemasaran (Kusnadi 2011), sedangkan harga yang ditambahkan sebenarnya untuk diberikan kepada perantara sesuai dengan kesepakatan penjual dan pembeli, serta biasanya dibebankan kepada penjual. Persentase dari harga yang dibayar oleh konsumen merupakan harga yang diterima oleh peternak atau oleh penjual di Pasar Hewan Bolu sebagai imbalan dari hasil kegiatan jual beli. Transaksi jual beli juga masih banyak dilakukan antara peternak dengan peternak atau pedagang dengan pedagang. Namun hal itu tidak dijadikan sebagai penghambat transaksi, sebaliknya sebagai tatanan perputaran perekonomian di setiap pasar atau di setiap rumah tangga peternak. Untuk melakukan transaksi jual beli ternak, beberapa peternak melakukan penjualan secara langsung di pasar hewan, dengan alasan untuk memperoleh haga jual yang lebih baik atau mengharapkan pembayaran secara tunai.

Soekartawi (1995) menyatakan bahwa efisiensi tataniaga merupakan salah satu komponen penting dalam menciptakan sistem tataniaga yang dapat memberikan keuntungan kepada berbagai pihak yang terkait dalam tataniaga. Oleh karena itu, tataniaga yang efisien akan berpengaruh terhadap pembentukan tingkat harga. Sedangkan saluran tataniaga merupakan pergerakan komoditas dari pihak produsen ke pihak konsumen melalui lembaga tataniaga. Panjang pendeknya saluran tataniaga yang dilalui oleh suatu hasil peternakan tergantung dari beberapa faktor, seperti jarak antara produsen ke konsumen, cepat tidaknya produk rusak, skala produksi dan posisi keuangan pengusaha. Alur pemasaran ternak kerbau di Pasar Hewan Bolu, Toraja Utara disajikan dalam Gambar 1. 


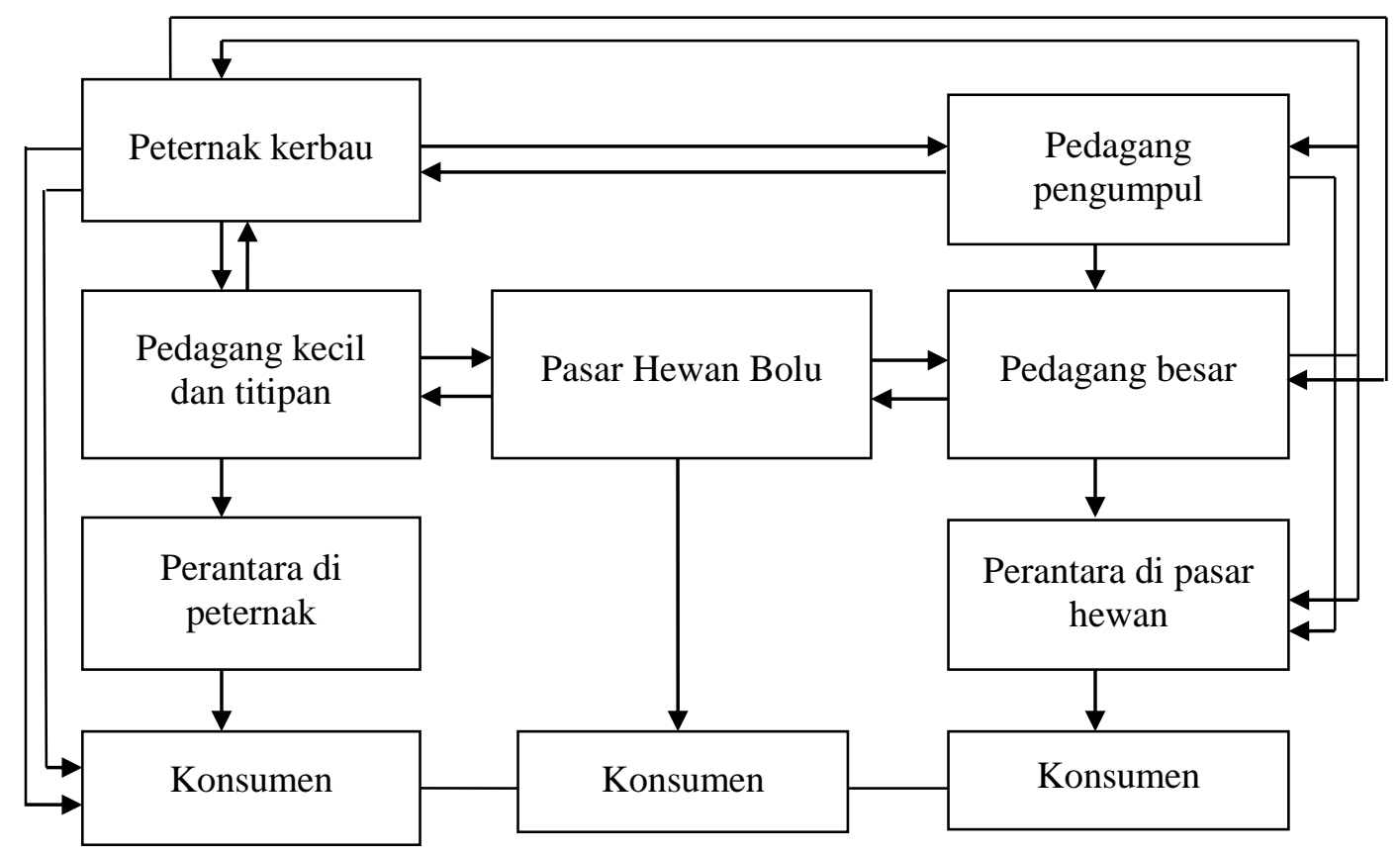

Gambar 1. Alur pemasaran ternak kerbau di Pasar Hewan Bolu Toraja Utara

Dalam Gambar 1 terlihat bahwa alur pemasaran ternak kerbau d Pasar Hewan Bolu mempunyai kemiripan dengan alur pemasaran ternak domba di kabupaten Indramayu. (Wibowo et al. 2016) yakni terjadinya penitipan ke pedagang titipan untuk ternak kerbau yang tidak laku terjual.

\section{Biaya, marjin pemasaran ternak kebau}

Marjin pemasaran merupakan selisih antara harga yang dibayar konsumen akhir dengan biaya yang dikeluarkan petani (produsen). Biaya yang dikeluarkan oleh setiap pedagang bervariasi tergantung pada jarak daerah pemasaran. Volume ternak kerbau yang biasanya dijual oleh pedagang besar di Pasar Hewan Bolu berkisar antara 10-20 ekor. Sedangkan untuk pedagang kecil antara 1-2 ekor. Untuk pedagang titipan, sangat tergantung oleh banyaknya ternak kerbau yang tidak terjual, dengan kisaran antara 2-8 ekor/kandang.

Hasil wawancara dengan pedagang yang ditemui, menunjukkan biaya produksi selama di pasar hewan, meliputi biaya transportasi Rp. 150.000/ekor, biaya pemeliharaan pakan dan vitamin sebesar Rp. 25.000/ekor/6 hari, biaya tenaga kerja Rp. 50.000/ekor/6 hari dan biaya restribusi pasar sebesar Rp.2.500/ekor/6 hari, sehingga total biaya pemasaran ternak kebau di Pasar Hewan Bolu, Toraja Utara sebesar Rp. 615.000/ekor/pedagang/6 hari. Dari gambaran harga ternak dan biaya yang dikeluarkan, maka dapat dihitung marjin pemasaran ternak kerbau seperti yang disajikan dalam Tabel 1.

Dalam Tabel 1 terlihat bahwa dalam menentukan harga penjualan pedagang akan mematok harga berdasarkan harga perolehan ternak, ditambah dengan biaya lain-lain. Namun demikian, karena pelaku pemasarannya cukup banyak dan beragam, maka dalam menentukan marjin keuntungan harus disesuaikan atau dipertimbangkan dengan harga yang berlaku dari pedagang lainnya. Besarnya marjin keuntungan pedagang dalam penjualan ternak di pasar pada minggu I berkisar antara 8-10\% dengan pertimbangan harga cukup kompetitif untuk jenis dan kualitas ternak. 
Tabel 1. Marjin pemasaran pelaku pasar ternak kerbau (per ekor/6 hari)

\begin{tabular}{|c|c|c|c|c|c|c|c|}
\hline \multicolumn{3}{|c|}{ Rata-rata harga hari pasar I (Rp) } & \multicolumn{5}{|c|}{ Rataa-rata harga hari pasar II (Rp) } \\
\hline Harga awal & Harga jual & Marjin & Biaya & $\begin{array}{l}\text { Risiko } \\
(10 \%)\end{array}$ & Hars & $\begin{array}{c}\text { Marjin } \\
\text { pedagang } \\
\text { titipan }\end{array}$ & $\begin{array}{c}\text { Marjin } \\
\text { pedagang } \\
\text { pengumpul }\end{array}$ \\
\hline 19.500 .000 & 20.200 .000 & 700.000 & 615.000 & 1.950 .000 & 20.835 .000 & 520.875 & 814.125 \\
\hline 21.700 .000 & 22.500 .000 & 800.000 & 5.000 & 2.170 .000 & 23.255 .000 & 581.375 & 973.625 \\
\hline 19.715 .000 & 20.750 .000 & 1.035 .000 & 615.000 & 1.971 .500 & 21.071.500 & 526.788 & 829.713 \\
\hline 18.550 .000 & 19.800 .000 & 1.250 .000 & 615.000 & 1.855 .000 & 19.790 .000 & 494.750 & 745.250 \\
\hline 21.125 .000 & 24.600 .000 & 3.475 .000 & 615.000 & 2.112 .500 & 22.622 .500 & 565.563 & 931.938 \\
\hline 16.600 .000 & 17.821 .428 & 1.221 .428 & 615.000 & 1.660 .000 & 17.645 .000 & 441.125 & 603.875 \\
\hline 14.420 .000 & 15.250 .000 & 830.000 & 615.000 & 1.442 .000 & 15.247 .000 & 381.175 & 445.825 \\
\hline
\end{tabular}

Sumber: Distannak Kabupaten Toraja Utara (2016) angka dihitung kembali

Untuk harga pokok penjualan pada minggu II sebagai akibat dari ternak yang tidak terjual pada minggu I, maka pedagang (pemilik ternak) harus memperhitungkan biaya pemeliharaan (Rp. 615.000) dan biaya risiko atas ternak yang belum terjual, sebesar 10\% dari harga awal pembelian ternak. Kemudian dari biaya risiko tersebut terdapat bagian untuk pedagang titipan sebesar 2,5\% dari harga jual pada minggu II dan sisa biaya risiko sebesar 7,5\% dari harga jual merupakan hak pedagang pengumpul (pemilik ternak) dan selanjutnya akan terakumulasi dengan keuntungan per ekor ternak yang terjual.

Apabila dalam kenyataannya jumlah ternak yang dijual pada pasar minggu I terjual habis maka perhitungan harga pokok penjualan pada pasar minggu II menjadi tidak berlaku. Namun, apabila pada minggu II masih ada sisa ternak yang belum terjual, maka pemilik akan terbebani lagi dengan biaya pemeliharaan ternak.

Marjin pemasaran ini mempunyai rantai yang panjang, tetapi tidak menjadi kendala bagi para pedagang di Pasar Hewan Bolu. Hal tersebut sudah menjadi kebiasaan di setiap pasar hewan di wilayah-wilayah di Indonesia. Menurut Elizabeth et al. (2013), penjualan termak ruminansia seperti kambing atau domba, di petani selalu lebih murah dibandingkan dengan pedagang kecil (belantik desa dan pedagang besar), peternak tidak memperhitungkan ongkos dan tenaga kerja, dianggap sudah cukup memenuhi kebutuhan pada saat dibutuhkan.

\section{KESIMPULAN}

Ternak kerbau memegang peranan yang sangat penting bagi status sosial dan budaya masyarakat di wilayah Tana Toraja, Sulawesi Selatan. Keberadaan ternak kerbau dimanfaatkan pada acara-acara tertentu sebagai simbol kebesaran seperti pada acara kematian bagi anggota keluarga yang meninggal dunia, sehingga menjadi menarik sebagai komoditas perdagangan ternak. Dalam transaksi jual beli ternak melibatkan ragam pelaku pasar dan dalam aktivitasnya pedagang pengumpul mendapat marjin pemasaran antara 8$10 \%$ dari harga pokok pembelian, sedangkan pedagang titipan mendapat marjin pemasaran $2,5 \%$.

\section{DAFTAR PUSTAKA}

Abubakar R. 2002. Ekonomi pemasaran, proyek dan pengadaan buku ekonomi. Jakarta (Indonesia): PT Sumber Bahagia. 
Disnak Kabupaten Toraja Utara. 2012. Laporan tahunan Dinas Peternakan Kabupaten Toraja Utara tahun 2012. Rantepao (Indonesia): Dinas Peternakan Kabupaten Toraja Utara.

Disnak Provinsi Sulawesi Selatan. 2013. Populasi ternak kerbau di Provinsi Sulawesi Selatan tahun 2013. Makassar (Indonesia): Dinas Peternakan Provinsi Sulawesi Selatan.

Distannak Kabupaten Toraja Utara. 2016. Pewilayahan di Kabupaten Tana Toraja, Statistik Pertaian, dalam angka sementara 2015. Rantepao (Indonesia): Dinas Pertanian dan Peternakan Kabupaten Toraja Utara.

Elizabeth R, Rusdiana S, Romjali E. 2013. Marjin pemasaran ternak ruminasia (kambing) dalam pemenuhan kebutuhan konsumen: Analisis ekonomi. Dalam: Djoko M, Harisdudin, Danar P, Adi MPN, Rahayu, Widiyanto, Rysca I, Yuli Y, Setya HB, penyunting. Prosiding Seminar Nasional. Surakarta (Indonesia): Program Studi Agribisnis, Fakultas Pertanian, Universitas Sebelas Maret. Hlm. 331-337.

Elizabeth R, Rusdiana S. 2011. Analisis ekonomi pendapatan usaha domba mendukung kesejahteraan petani. Dalam: Mimin M, Nandang S, Marsetio, Nana S, Bambang N, Muhamad D, Edy S, Agus N, Ikin S, Imas SS, Indira LK, penyunting. Prosiding Seminar Nasional Peternakan Berkelanjutan III. Bandung, 2-3 November 2011. Bandung (Indonesia): Fakultas Peternakan, Universitas Padjadjaran. hlm. 245-252.

Emhar A, Aji JMM, Agustina T. 2014. Analisis rantai pasokan (supply chain) daging di Kabupaten Jember. J Berkah Ilmiah Pertanian. 2:53-61.

Kotler, Amstrong. 1992. Manajemen pemasaran analisis perencanaan implementasi dan pengendalian. Edisi kedelapan. Jakarta (Indonesia): Salemba Empat.

Kusnadi U. 2011. Nilai ekonomi tataniaga kerbau dari Kabupaten Padeglang dan Kabupaten Lebak Provinsi Banten. Dalam: Prasetyo LH, Damayanti R, Iskandar S, Herawati T, Priyanto D, Puastuti P, Anggraeni A, Tarigan S, Wardhana AH, Dharmayanti NLPI, penyunting. Teknologi Peternakan dan Veteriner untuk Peningkatan Produksi dan Antisipatif terhadap Dampak Perubahan Iklim. Prosiding Seminar Nasional Teknologi Peternakan dan Veteriner. Bogor, 7-8 Juni 2011. Bogor (Indonesia): Puslitbangnak. hlm. 217-226.

Panggau N. 2014. Perubahan harga jual ternak kerbau pada masa tunggu oleh pelaku pemasaran di Pasar Hewan Bolu Kecamatan Tallanglipu Kabupaten Toraja Utara. Makassar (Indonesia): Fakultas Peternakan, Universitas Hasanudin.

Saleh IM, Sirajuddin SN, Abdullah A, Aminawar M. 2012. Pengaruh populasi dan tingkat pemotongan terhadap pengembangan agribisnis ternak kerbau di Kabupaten Toraja Utara. Dalam: Prosiding Seminar Nasional Pengembangan Agribisnis Peternakan Menuju Swasembada Protein Hewani. Purwokerto (Indonesia): Universitas Jenderal Soedirman. hlm. 223.

Sariubang M, Qomariyah R, Kristanto L. 2010. Peran ternak kerbau dalam masyarakat adat Toraja di Sulawesi Selatan. Dalam: Prasetyo LH, Natalia L, Iskandar S, Puastuti P, Herawati T, Nurhayati, Anggraeni A, Damayanti R, Dharmayanti NLPI, Estuningsih SE, penyunting. Teknologi Peternakan dan Veteriner Ramah Lingkungan dalam Mendukung Program Swasembada Daging dan Peningkatan Ketahanan Pangan. Prosiding Seminar Nasional Teknologi Peternakan dan Veteriner. Bogor, 3-4 Agustus 2010. Bogor (Indonesia): Puslitbangnak.

Soekartawi. 1995. Manajemen pemasaran hasil pertanian, teori dan aplikasinya. Jakarta (Indonesia): CV Rajawali.

Wibowo B, Rusdiana S, Adiati U. 2016. Pemasaran ternak domba di Pasar Hewan Palasari Kabupaten Indramayu, Jawa Barat. Agroekonomika. 5:85-93.

Yulius NA. 2012. Penentuan harga jual kerbau belang berdasarkan karakteristik di Pasar Hewan Bolu kecamatan Tallanglipu Kabupaten Toraja Utara. Makassar (Indonesia): Fakultas Peternakan, Universitas Hasanudin. 